\title{
ATP1B3 wt Allele
}

National Cancer Institute

\section{Source}

National Cancer Institute. ATP1B3 wt Allele. NCI Thesaurus. Code C132088.

Human ATP1B3 wild-type allele is located in the vicinity of 3q23 and is approximately 50 $\mathrm{kb}$ in length. This allele, which encodes sodium/potassium-transporting ATPase subunit beta-3 protein, is involved in sodium/potassium ion exchange. 